Revista Brasileira de

Engenharia Agrícola e Ambiental

v. 15 , n. 8 , p. $845-852,2011$

Campina Grande, PB, UAEA/UFCG - http://www.agriambi.com.br

agriambi

Protocolo 143.09 - 30/09/2009 • Aprovado em 01/06/2011

\title{
Periods of constant and falling-rate for infrared drying of carrot slices
}

\author{
Fernando M. Botelho', Paulo C. Corrêa ${ }^{2}$, André. L. D. G oneli ${ }^{3}$, Márcio A. Martins', \\ Felipe E. A. Magalhães ${ }^{2} \&$ Sílvia C. Campos ${ }^{4}$
}

\begin{abstract}
The aim of this w ork was to study the infrared drying process of carrot slices and to determine coefficients related to the heat and mass transfer of the process. Fresh carrots were used, dried until constant weight in a dryer with infrared heating source. Different models were utilized to fit the experimental data of constant and falling drying rate periods. It was verified that the coefficients of heat and mass transfer, during the constant drying rate, significantly increased with temperature on rise. The Diffusion Approximation, Two Terms, Midili and Verna models satisfactory represented the falling period of drying rate of carrot slices. The effective diffusion coefficient increased with temperature and this relationship can be represented by the Arrhenius equation, obtaining activation energy to the drying process of $29.092 \mathrm{~kJ} \mathrm{~mol}^{-1}$.
\end{abstract}

Key words: modeling, dehydration, water diffusion

\section{Períodos de secagem constante e decrescente de fatias de cenoura por infravermelho}

\begin{abstract}
RESU MO
Com este trabalho objetivou-se estudar o processo de secagem por infravermelho das fatias de cenoura e determinar alguns coeficientes referentes à transferência de calor e massa do processo. U tilizaram-se cenouras frescas, secadas até massa constante em um secador com fonte de aquecimento por infravermelho. Aos dados experimentais se ajustaram diferentes modelos para os períodos de taxa de secagem constante e decrescentes. Verificou-se que os coeficientes transferência de calor e massa, referentes ao período de secagem constante, aumentaram significativamente com o aumento da temperatura e que os modelos Aproximação da Difusão, Dois Termos, Midili e Verna representaram satisfatoriamente o período de secagem decrescente das fatias de cenoura. 0 coeficiente de difusão efetivo aumentou com a temperatura e esta relação pode ser representada pela Equação de Arrhenius, obtendo-se uma energia de ativação para o processo de secagem de $29,092 \mathrm{~kJ} \mathrm{~mol}^{-1}$.
\end{abstract}

Palavras-chave: modelagem, desidratação, difusão de água

${ }^{1}$ ICAA/U FM T, Av. Alexandre Ferronato, 1200, Setor Industrial, CEP 78557-267, Sinop, MT. Fone: (66) 3531-1663. E-mail: fernandobotelho@ufmt.br DEA/UFV, Centreinar - Campus UFV, CEP 36570-000, Viçosa, MG. Fone: (31) 3899-2030. E-mail(s): copace@ufv.br; aredes@ufv.br; eaafelipe@hotmail.com

${ }^{3}$ FCA/U FGD, Rod. Dourados - Itahum, km 12 Campus Universitário, CEP 79804-970, Dourados, MS, C.P. 533. Fone: (67) 3410-2407. E-mail: andregoneli@ufgd.edu.br

${ }^{4}$ Embrapa Agrossilvipastoril, Av. dos Jacarandás, 2639, Centro, CEP 78550-003, Sinop, MT. Fone: (66) 3532-7626. E-mail: silvia.campos@embrapa.br 


\section{INTRODUCTION}

Carrot, as most vegetables, has a limited shelf life which depends on room environment conditions it will be exposed to. Cold storage with controlled atmosphere is one of the most applied methods in order to preserve its quality and minimize post-harvest losses. Another alternative for storage is through dehydrating the product. Preservation through drying is based on the fact that both microorganisms and enzymes, and also the metabolic mechanism are dependent on water for their activity. As available water reduces, water activity and chemical reactions rates will also reduce. Therefore, the development of microorganisms will reduce.

Drying process is the most common process of agricultural products, in which heat is transferred from the heated air to the product by convection, and later the evaporated water is also transported to the air by convection. In convective drying, resistances to the heat and mass transfer are in the boundary layer and their magnitude is dependent on air velocity, or more generally on the Reynold's number. On the other hand, resistances to heat and mass transfer in the material during drying are high and strongly affect kinetics of the water evaporation. Convective drying usually requires a great amount of time and causes many undesirable changes in the material (Nowak \& Lewicki, 2004). Therefore, drying of agricultural products involving faster and more thermally effective techniques, and the use of microwaves and infrared radiation have been studied by several researches (Hebbar \& Rostagi, 2001; Afzal \& Abe, 1998; Toğrul, 2006; Nowak \& Lewicki, 2004). Infrared radiation heating offers many advantages over conventional drying under similar drying conditions. Infrared radiation is used to heat or dry moist materials, in which the radiation penetrates the exposed material and the energy of radiation converts into heat. The depth of penetration depends on the property of the material and wavelength of radiation. When a material is exposed to radiation, it is intensely heated and the temperature gradient in the material reduces within a short period of time. Results of infrared drying compared to conventional drying allowed to conclude that this process provides a more uniformly heated product, resulting in better quality characteristics (Hebbar \& Rastagi, 2001).

In scientific and technical literature, several models have been proposed to analyze and simulate drying process in hygroscopic products. Processes which are subjected of modeling, such as drying, may fit into one of the three categories: those of theoretical fundaments, empiric and semitheoretical. The first is based on scientific laws and theories. Usually, they are complex and involve many functions and parameters, most cases inconvenient for computer practices (Maskan, 2002). Even though empirical models lack theoretical fundaments, they are simpler and easily applied. Its use is based on experimental data and non-dimensional analysis (Brooker et al., 1992). Semi-theoretical models are simplifications and/or adjustment of theoretical models, mainly those based on the theory of liquid diffusion from Fick's Law and on Newton's theory of cooling. Every model proposed to model drying processes fit only a falling-rate drying period. Agricultural products which contain high moisture content, if submitted to a drying process in which air condition are kept constant, would have a thin layer of water on their surface; this water is immediately replaced by the product during drying. During this period, weight variation is constant, which means, drying rate is constant. This process occurs due to a much lower intern resistance for water transport than the one to remove moisture from the surface of the product. Therefore, modeling a process becomes a conjugated system composed of a period of constant rate and another of falling-rate during drying. Critical moisture content is the one in which the rate of water loss is not constant, becoming a falling-rate.

Depending on which material is drying, moisture content may move inside it by different mechanisms. In hygroscopic capillary-porous products, as most agricultural products, possible transport mechanisms of moisture content are: liquid diffusion, capillary diffusion, diffusion on the surface, hydrodynamic flow, vapor diffusion and thermal diffusion (Brooker et al., 1992). The mechanism by which water diffusion occurs in agricultural products is very complex due to the diversity of chemical contents and physical structures of products. In literature about drying involving the phenomenon of water diffusion, considerable variations of diffusivity coefficients are found, not only due to the complexity of products but also as a function of different prediction methods, types of material, moisture content, drying process and the methodology used to obtain it. For the theoretical calculation of effective diffusion coefficient of agricultural products, several researches have based on the theory of liquid diffuse, known as Fick's Second Law. It establishes a relationship between diffusion coefficient and concentration gradient of a solution. Regarding the presented points and the experiment of infrared drying of carrots, the objective of this experiment was to evaluate and estimate drying curves, to determine global convective heat and mass transfer coefficient for a period of constant rate, as well as to determine the effective diffusion coefficient for several drying temperatures for the carrot of Brasília variety.

\section{Material AND METHODS}

The present research was developed at the Laboratory of Physical Properties and Quality of Agricultural Products, at the National Storage Training Center (Centro Nacional de Treinamento em Armazenagem - CENTREINAR), located at the Federal University of Viçosa, Viçosa, MG, Brazil.

\section{Determination and modeling of drying curves}

Carrots were obtained from the local market and stored in BOD under temperatures of $5 \pm 1{ }^{\circ} \mathrm{C}$ during the experiment. Initial moisture content of carrot was $10.24 \mathrm{~kg}_{\mathrm{w}} \mathrm{kg}_{\mathrm{dm}}{ }^{-1}$ (kilogram of water per kilogram of dry matter) and they were dried until reach constant weight, meaning a weight variation lower than $0.001 \mathrm{~kg}_{\mathrm{w}} \mathrm{kg}_{\mathrm{dm}}{ }^{-1}$.

Carrot slices were whitened in Sodium hydrogen sulfite solution $\left(\mathrm{NaHSO}_{3}\right) 0.1 \%(\mathrm{~m} / \mathrm{v})$ for fifteen minutes in order to avoid darkening of the product during drying process by enzyme activity (peroxidase). Half slab thickness of carrots 
was $1.5 \mathrm{~mm}$ and the average weight was about $2 \mathrm{~g}$. Besides half slab thickness, the diameter of each slice was measured in its orthogonal positions, and the average of the last measures was used for further calculations. The dimension was obtained utilizing a digital caliper $0.01 \mathrm{~mm}$ of precision. An infrared drier accompanied by a weighing scale of $0.001 \mathrm{~g}$ precision was used in order to dry the product under temperatures of 50,60, $70,80,90$ and $100^{\circ} \mathrm{C}$. The measures of the drier were obtained in an interval of 1 minute.

Theories which analyze constant-rate periods of drying processes of agricultural products may be approximate to theories about heat and mass transference balances for wetbulb thermometer. Therefore, constant-rate drying may be represented by Eq. 1 (Brooker et al., 1992):

$$
\frac{\mathrm{dM}}{\mathrm{dt}}=\frac{\mathrm{h}_{\mathrm{c}} \mathrm{A}}{\mathrm{h}_{\mathrm{fg}}}\left(\mathrm{T}-\mathrm{T}_{\mathrm{bu}}\right)=\frac{\mathrm{h}_{\mathrm{m}} \mathrm{A}}{\mathrm{R}_{\mathrm{v}}}\left(\frac{\mathrm{P}_{\mathrm{vbu}}}{\mathrm{T}_{\mathrm{bu}}}-\frac{\mathrm{P}_{\mathrm{v} \infty}}{\mathrm{T}}\right)
$$

in wich:

$\mathrm{h}_{\mathrm{c}}$ - global convective heat transfer coefficient, $\mathrm{W} \mathrm{m}^{-2}{ }^{\circ} \mathrm{C}$

$\mathrm{h}_{\mathrm{m}}$ - global convective mass transfer coefficient, $\mathrm{m} \mathrm{s}^{-1}$

$\mathrm{h}_{\mathrm{fg}}$ - latent heat of vaporization, $\mathrm{J} \mathrm{kg}^{-1}$

$\mathrm{R}_{\mathrm{v}}^{\mathrm{fg}}$ - universal water vapor constant, $0.462 \mathrm{~J} \mathrm{~kg}^{-1} \mathrm{~K}^{-1}$

A - area, $\mathrm{m}^{2}$

$\mathrm{T}$ - drying temperature, ${ }^{\circ} \mathrm{C}$

$\mathrm{T}_{\text {bu }}$ - wet bulb temperature, ${ }^{\circ} \mathrm{C}$

$\mathrm{P}_{\mathrm{v} \infty}$ - vapor pressure, $\mathrm{Pa}$

$\mathrm{P}_{\mathrm{vbu}}^{\mathrm{v} \infty}$ - vapor pressure for wet-bulb temperature, $\mathrm{Pa}$

$\mathrm{dM} / \mathrm{dt}$ - constant drying rate, $\mathrm{kg} \mathrm{s}^{-1}$

In order to model the period of falling-rate drying, experimental data of carrot slices were fitted to mathematical models shown by Eqs. 2 to 9. These equations, shown in Table 1 , are frequently used to describe drying phenomenon of agricultural products.

Table 1. Mathematical Models for modeling drying of agricultural products

\begin{tabular}{|c|c|c|}
\hline Model designation & Model & Eq. \\
\hline $\begin{array}{c}\text { Diffusion } \\
\text { approximation }\end{array}$ & $R U=a \exp (-k t)+(1-a) \exp (-k b t)$ & (2) \\
\hline Two terms & $R U=a \exp (-k t)+b \exp (-g t)$ & (3) \\
\hline Henderson \& Pabis & $\mathrm{RU}=\mathrm{a} \exp (-\mathrm{kt})$ & (4) \\
\hline Logarithm & $R U=a \exp (-k t)+b$ & (5) \\
\hline Midili & $R U=a \exp \left(-k t^{\mu}\right)+b t$ & (6) \\
\hline Page & $\mathrm{RU}=\exp \left(-k t^{\mu}\right)$ & (7) \\
\hline Thompson & $R U=\exp \left\{\left[-a-\left(a^{2}+4 b t\right)^{0,5}\right] / 2 b\right\}$ & (8) \\
\hline Verna & $R U=a \exp (-k t)+(1-a) \exp (-g t)$ & (9) \\
\hline
\end{tabular}

where:

RU - moisture ratio, dimensionless

$\mathrm{T}$ - time, $\min$

$\mathrm{K}$ - drying constant, $\min ^{-1}$

a, b, c, g, h, $\mu$ - models coefficients.

Moisture ratio (RU) was simplified according to Eq. 10, in which in equilibrium moisture content, it is considered to be zero. This simplification is due to the fact that through infrared drying, samples may be dried as much as dry matter content (Toğrul, 2006).

$$
\mathrm{RU}=\frac{\mathrm{U}_{\mathrm{t}}-\mathrm{U}_{\mathrm{e}}}{\mathrm{U}_{0}-\mathrm{U}_{\mathrm{e}}} \cong \frac{\mathrm{U}_{\mathrm{t}}}{\mathrm{U}_{0}}
$$

where:

$\mathrm{U}_{\mathrm{t}}$ - moisture content in a given period of time, $\mathrm{kg}_{\mathrm{w}} \mathrm{kg}_{\mathrm{dm}}{ }^{-1}$

$\mathrm{U}_{\mathrm{e}}$ - equilibrium moisture content, $\mathrm{kg}_{\mathrm{w}} \mathrm{kg}_{\mathrm{dm}}{ }^{-1}$

$\mathrm{U}_{\mathrm{o}}$ - initial moisture content, $\mathrm{kg}_{\mathrm{w}} \mathrm{kg}_{\mathrm{dm}}{ }^{-1}$

\section{Statistical analysis}

For adjusting mathematical models, a non-linear regression analysis was conducted, by Gauss Newton method, using STATISTICA $6.0^{\circledR}$ software. The model adjustment level of each model considered the magnitude of the determination coefficient $\left(\mathrm{R}^{2}\right)$, the magnitude of the mean relative error (MRE) and the magnitude of standard error of estimate (SEE). The relative average error and the standard error of estimate, for each of the models, were calculated by Eqs. 11 and 12 .

$$
\begin{aligned}
\text { MRE } & =\frac{100}{\eta} \sum_{i=1}^{\eta}\left(\frac{\left|M_{\text {exp }}-M_{\text {pre }}\right|}{M_{\text {exp }}}\right) \\
\mathrm{SEE} & =\sqrt{\frac{\sum_{i=1}^{\eta}\left(\mathrm{M}_{\exp }-\mathrm{M}_{\mathrm{pre}}\right)^{2}}{\mathrm{D}_{\mathrm{f}}}}
\end{aligned}
$$

where:

$\mathrm{M}_{\text {exp }}$ - experimental value

$M_{\text {pre }}^{\text {exp }}$ - value predicted by the model

$D_{f}^{p r e}$ - degrees of freedom of regression

$\eta$ - number of data points

\section{Determination of the effective diffusion coefficient $\left(D_{\text {ef }}\right)$}

The effective diffusion coefficient was obtain by the adjustment of mathematical model of liquid diffusion, described by Eq. 13, to the experimental data for drying of carrot slices. This equation is the analytical solution of Fick's Second Law, considering the slab geometrical form (plate), conditions of moisture content on surface of the product and not taking into consideration volumetric shrinkage of the product.

$$
\mathrm{RU}=\frac{8}{\pi^{2}} \sum_{\mathrm{i}=1}^{\mathrm{n}} \frac{1}{(2 \mathrm{n}+1)^{2}} \exp \left[-\frac{(2 \mathrm{n}+1)^{2} \pi^{2} \mathrm{D}_{\mathrm{ef}} \tau}{4 \mathrm{~L}^{2}}\right]
$$

where:

$D_{\text {ef }}$ - effective diffusion coefficient, $\mathrm{m}^{2} \mathrm{~s}^{-1}$

$n$ - numbers of terms in the equation

L - half thickness, $\mathrm{m}$

$\tau$ - time, $\mathrm{s}$ 
The analytical solution of this equation is presented as infinite series and, therefore, the finite number of terms (n) may determine the precision of results.

\section{Influence of temperature}

In order to evaluate the influence of temperature in the effective diffusion coefficient, several researches have utilized Arrhenius relationship, Eq. 14 (Doymaz, 2006; Gely \& Giner, 2007; Gely \& Santalla, 2007).

$$
\mathrm{D}_{\mathrm{ef}}=\mathrm{D}_{0} \exp \left(\frac{\mathrm{E}_{\mathrm{a}}}{\mathrm{RT}_{\mathrm{abs}}}\right)
$$

where:

$$
\begin{aligned}
& \mathrm{D}_{0} \text { - pre-exponential factor, } \mathrm{m}^{2} \mathrm{~s}^{-1} \\
& \mathrm{E}_{\mathrm{a}} \text { - activation energy, } \mathrm{kJ} \mathrm{mol}^{-1} \\
& \mathrm{R} \text { - universal gas constant, } 8,314 \mathrm{~J} \mathrm{~mol}^{-1} \mathrm{~K}^{-1} \\
& \mathrm{~T}_{\mathrm{abs}} \text { - absolute temperature, } \mathrm{K}
\end{aligned}
$$

\section{RESULTS AND DISCUSSION}

The values observed for moisture content in decimal dry bases as a function of time for all the conditions of drying temperatures are shown in Figure 1A.

From Figure 1A, it can be observed that as drying temperature increased, the values of moisture content rapidly decreased; and as a consequence, drying period decreased. This variation was approximately 4.2 times with temperature increase from 50 to $100^{\circ} \mathrm{C}$. It can be also observed that at the beginning of drying process, carrots presented constant drying period. Usually, this behavior is observed in drying of agricultural products.

For analysis of the period of constant drying, critical moisture content for all drying conditions was considered equal to $4.2 \mathrm{~kg}_{\mathrm{w}} \mathrm{kg}_{\mathrm{dm}}{ }^{-1}$, in accordance to observations of water loss variations.

Figure 1B presents a scheme of the constant drying period, in which it was only considered the average of initial and final moisture content for each drying temperature as a function of time.

In accordance to Figure $1 \mathrm{~B}$, it can be noticed that the period to which the drying of carrot slices was no longer constant decreased approximately in an arithmetical progression, varying from 4 to $14 \mathrm{~min}$, as temperature varied from 90 to $50^{\circ} \mathrm{C}$. There was no difference in the drying rate when temperature increased from 90 to $100{ }^{\circ} \mathrm{C}$. This is evidence that drying rates are not only ruled by temperature, but also by physical characteristics of the product.

The values for global convective mass and heat transfer coefficients for carrot slices under all condition in which the experiment was conducted are shown in Figure 2.

By Figure 2A and 2B it can be concluded that both global convective heat transfer coefficient $\left(h_{c}\right)$ and global convective mass transfer coefficient $\left(\mathrm{h}_{\mathrm{m}}\right)$ significantly increased as temperature increased, varying from 48.88 to $77.81 \mathrm{~W} \mathrm{~m}^{-2}{ }^{\circ} \mathrm{C}$

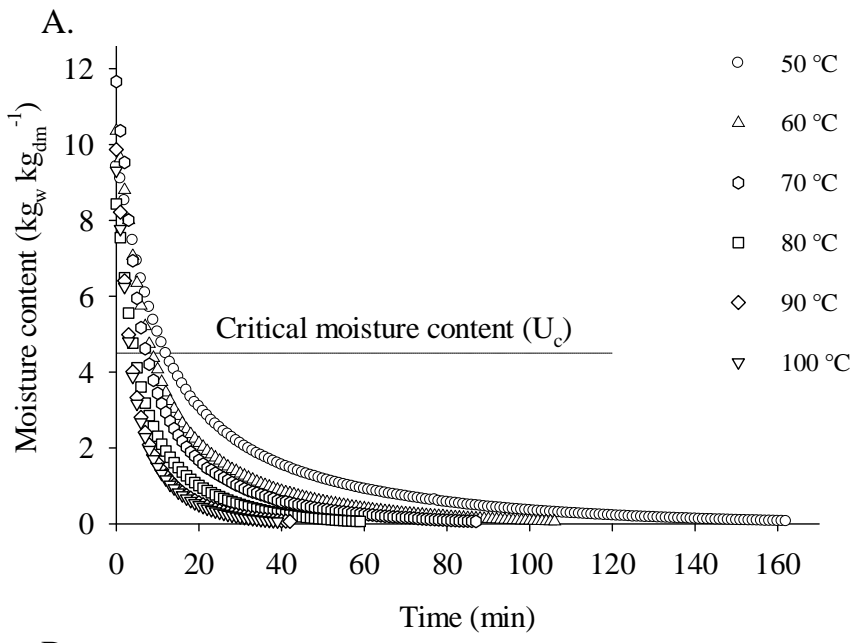

B.

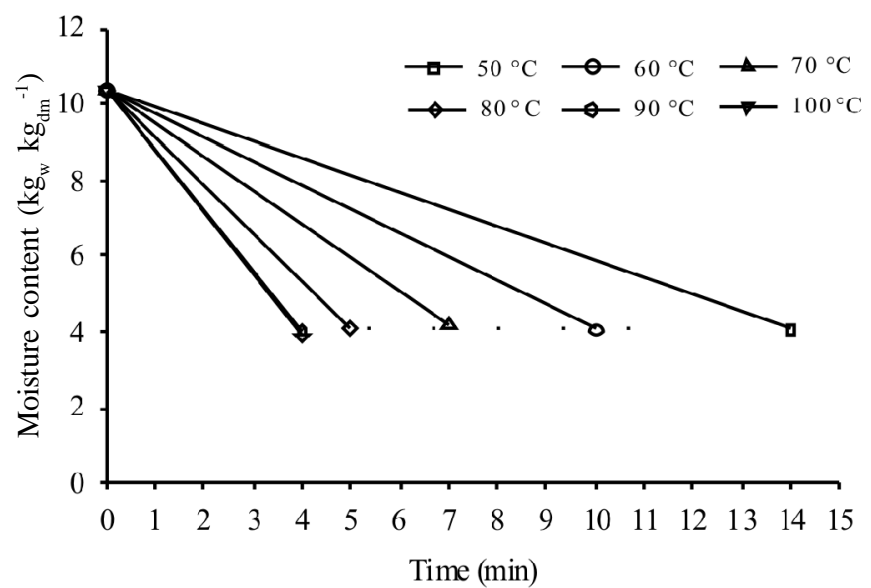

Figure 1. M oisture content variations of carrot slices in relation to time for each drying temperature $(A)$ and drying constant rate representation of carrot slices for each drying temperature utilized (B)

and 0.053 to $0.0984 \mathrm{~kg} \mathrm{~s}^{-1}$, respectively. For model analysis, results at $80^{\circ} \mathrm{C}$ were not considered.

Convective mass transfer coefficient defines the rate of mass transference without quantifying it. Therefore, this coefficient is important in order to explain variation of drying rates for several temperatures. Values of this coefficient support those found by Touré \& Kibangu-Nkembo (2004), who found 0.00974 $\mathrm{m} \mathrm{s}^{-1}$ for mango; $0.00475 \mathrm{~m} \mathrm{~s}^{-1}$ for manioc roots; and 0.00876 and $0.00943 \mathrm{~m} \mathrm{~s}^{-1}$ for two varieties of banana.

According to Bird et al. (2002), typical magnitude of heat transfer coefficients by free convection is between 3 and $20 \mathrm{~W}$ $\mathrm{m}^{-2}{ }^{\circ} \mathrm{C}^{-1}$, which are values lower than those found in this experiment. The main reason for this difference is that the phenomenon is not purely convective, but a conjugation of radiation and convective phenomenon. Besides, this coefficient depends on the condition of boundary layer, which is influenced by surface geometry, nature of fluid movement and several thermodynamics properties of fluid transport (Incropera \& DeWitt, 2002).

Table 2 shows statistical parameters of adjustment of each model to observed data in drying of carrot slices under temperature of $50,60,70,80,90$ e $100^{\circ} \mathrm{C}$, for a falling drying period. 
A.
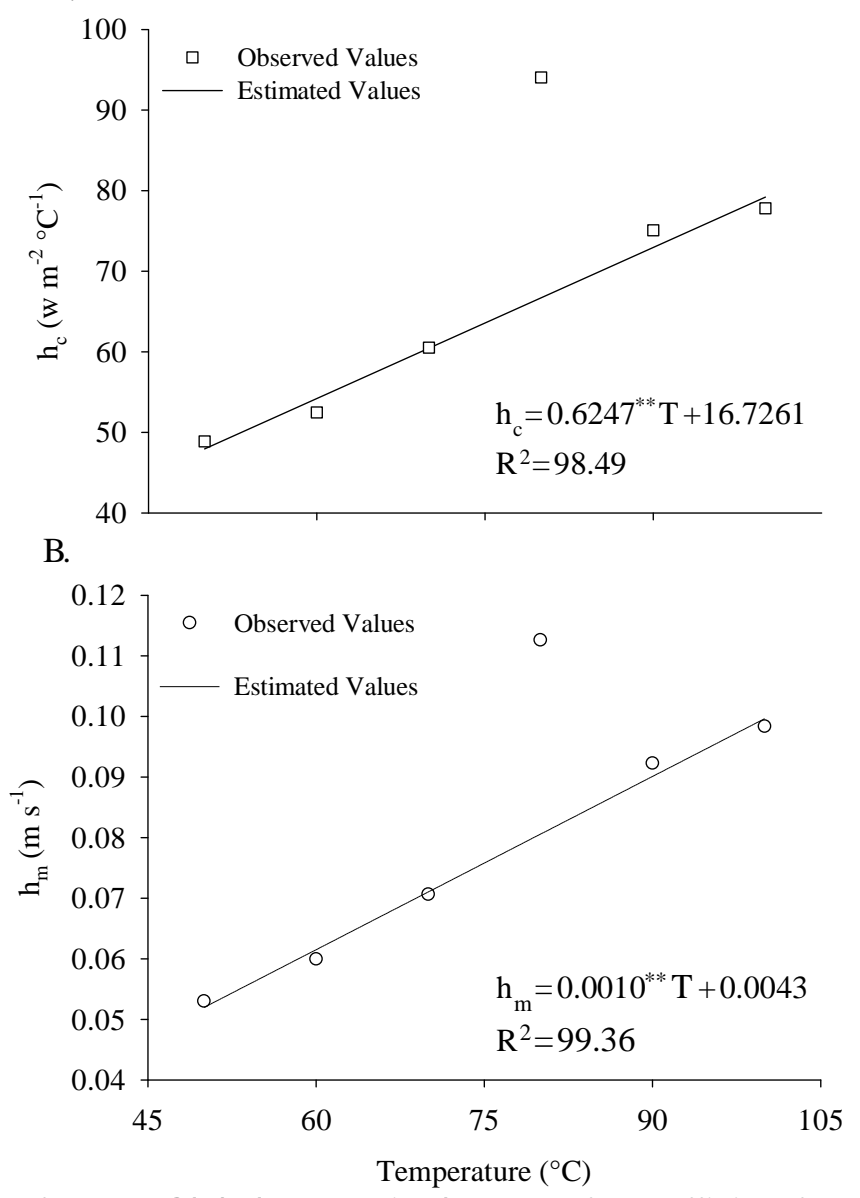

Figure 2. G lobal convective heat transfer coefficient for carrot slices in different drying temperatures $(A)$ and global convective mass transfer coefficient for carrot slices in different drying temperatures $(B)$

It is observed that for all drying temperatures, models used presented high values of determination coefficient, $\mathrm{R}^{2}$, (higher than 99\%). Even though this value is not recommended for modeling non-linear models, it normally follows a tendency, and it has higher values for models which better represent the phenomenon in consideration.

Also, it can be concluded from Table 2 that for all drying conditions, models 2, 3, 6 and 9 (Diffusion approximation, Two terms, Midili and Verna, respectively) were those which obtained the lowest values of standard error of estimate, SEE, always presenting values within order of magnitude of 0.0001 , for a variable which has its highest value within order of magnitude of 0.1 .

All the models, with exception of model 8 (Thompson) presents values of mean relative error, MRE, lower than $10 \%$ under all drying condition, which, according to Mohapatra \& Rao (2005) represents a good fit of experimental data. However, models 2, 3, 6 and 9 presented values much lower under all condition when compared to other models.

The coefficients of the model of Approximation Diffusion, two terms, Midili and Verna for each drying condition is shown in the Table 3.

The Approximation of Diffusion, Two terms, Midili and Verna models were those which presented the best results for representing the drying process of carrot slices. However, through a more detailed analysis of the coefficients it is possible to verify that only Verna model can describe with all its coefficients as a function of temperature.

Table 4 presents the resulting equation coefficient variation of Verna model, for different drying temperatures.

Therefore, Verna model may be presented with its coefficients described as a function of temperature, for modeling drying process of carrot slices, under temperature ranging from 50 to $100^{\circ} \mathrm{C}$, as described by Eq. 15 :

$$
\begin{aligned}
\mathrm{RU} & =0.37742 \exp [(-0.0016653 \mathrm{~T}+0.062201) \mathrm{t}]+ \\
& +0.62258 \exp [(-0.005636 \mathrm{~T}+0.184143) \mathrm{t}]
\end{aligned}
$$

Table 2. M ean relative error (M RE, \%), standard error of estimate (SEE) and determination coefficient $\left(\mathrm{R}^{2}, \%\right.$ ) of models

\begin{tabular}{|c|c|c|c|c|c|c|c|c|c|}
\hline \multirow{2}{*}{$\begin{array}{c}\text { Temperature } \\
\left({ }^{\circ} \mathrm{C}\right)\end{array}$} & \multirow{2}{*}{$\begin{array}{c}\text { Statistical } \\
\text { parameters }\end{array}$} & \multicolumn{8}{|c|}{ Mathematical models } \\
\hline & & 2 & 3 & 4 & 5 & 6 & 7 & 8 & 9 \\
\hline \multirow{3}{*}{50} & MRE & 1.4648 & 1.1404 & 13.250 & 2.5436 & 0.9934 & 5.4188 & 4.7463 & 1.4649 \\
\hline & SEE & 0.0059 & 0.0048 & 0.0569 & 0.0116 & 0.0052 & 0.0231 & 0.0182 & 0.0059 \\
\hline & $\mathrm{R}^{2}$ & 99.89 & 99.92 & 90.09 & 99.59 & 99.91 & 98.37 & 98.98 & 99.89 \\
\hline \multirow{3}{*}{60} & MRE & 1.4937 & 1.1451 & 2.4983 & 14.324 & 1.1040 & 5.9970 & 5.4462 & 1.4937 \\
\hline & SEE & 0.0064 & 0.0052 & 0.0113 & 0.0603 & 0.0053 & 0.0248 & 0.0204 & 0.0064 \\
\hline & $\mathrm{R}^{2}$ & 99.87 & 99.92 & 99.62 & 89.10 & 99.91 & 98.15 & 98.75 & 99.87 \\
\hline \multirow{3}{*}{70} & MRE & 1.8035 & 1.5320 & 18.085 & 3.8001 & 1.9245 & 7.4295 & 7.2197 & 1.8035 \\
\hline & SEE & 0.0065 & 0.0058 & 0.0664 & 0.0143 & 0.0081 & 0.0274 & 0.0236 & 0.0065 \\
\hline & $\mathrm{R}^{2}$ & 99.87 & 99.90 & 87.06 & 99.40 & 99.81 & 97.80 & 98.36 & 99.87 \\
\hline \multirow{3}{*}{80} & MRE & 0.9727 & 0.8383 & 12.426 & 2.0126 & 1.0319 & 5.1195 & 4.4389 & 0.9727 \\
\hline & SEE & 0.0044 & 0.0039 & 0.0586 & 0.0099 & 0.0057 & 0.0240 & 0.0190 & 0.0044 \\
\hline & $\mathrm{R}^{2}$ & 99.84 & 99.95 & 90.33 & 99.73 & 99.91 & 98.37 & 98.98 & 99.94 \\
\hline \multirow{3}{*}{90} & MRE & 1.1246 & 0.9832 & 13.517 & 2.2935 & 1.1744 & 5.3201 & 4.8538 & 1.1246 \\
\hline & SEE & 0.0050 & 0.0046 & 0.0632 & 0.0112 & 0.0062 & 0.0247 & 0.0206 & 0.0050 \\
\hline & $\mathrm{R}^{2}$ & 99.87 & 99.94 & 89.11 & 99.66 & 99.90 & 98.34 & 98.85 & 99.93 \\
\hline \multirow{3}{*}{100} & MRE & 0.9529 & 0.8550 & 13.388 & 2.1148 & 1.2009 & 5.3957 & 4.8940 & 0.9529 \\
\hline & SEE & 0.0044 & 0.0042 & 0.0637 & 0.0104 & 00066 & 0.0255 & 0.0212 & 0.0044 \\
\hline & $\mathrm{R}^{2}$ & 99.94 & 99.95 & 89.19 & 99.72 & 99.89 & 98.26 & 98.80 & 99.94 \\
\hline
\end{tabular}
studied to each drying temperature used 
Table 3. Coefficients of A pproximation diffusion models (2), Two terms (3), Midili (6) and Verna (9), under all temperatures for infrared drying

\begin{tabular}{|c|c|c|c|c|c|c|}
\hline \multirow{2}{*}{$\begin{array}{c}\text { Temperature } \\
\left({ }^{\circ} \mathrm{C}\right)\end{array}$} & \multirow{2}{*}{ Models } & \multicolumn{5}{|c|}{ Coefficients } \\
\hline & & $a$ & k & b & g & $\mathrm{n}$ \\
\hline 50 & $\begin{array}{l}2 \\
3 \\
6 \\
9\end{array}$ & $\begin{array}{l}0.592187 \\
0.988647 \\
1.174629 \\
0.407813\end{array}$ & $\begin{array}{l}0.103701 \\
0.124196 \\
0.230669 \\
0.023971\end{array}$ & $\begin{array}{c}0.231152 \\
0.416611 \\
-0.000055 \\
-\end{array}$ & $\begin{array}{c}- \\
0.024185 \\
- \\
0.103701\end{array}$ & $\begin{array}{c}- \\
- \\
0.577726 \\
-\end{array}$ \\
\hline 60 & $\begin{array}{l}2 \\
3 \\
6 \\
9\end{array}$ & $\begin{array}{l}0.624110 \\
0.369396 \\
1.143413 \\
0.375890 \\
\end{array}$ & $\begin{array}{l}0.153054 \\
0.037404 \\
0.287745 \\
0.037659\end{array}$ & $\begin{array}{c}0.246048 \\
0.519592 \\
-0.000053 \\
- \\
\end{array}$ & $\begin{array}{c}0.140671 \\
- \\
0.153054\end{array}$ & $\begin{array}{c}- \\
- \\
0.594960 \\
- \\
\end{array}$ \\
\hline 70 & $\begin{array}{l}2 \\
3 \\
6 \\
9\end{array}$ & $\begin{array}{l}0.685045 \\
0.306528 \\
1.388175 \\
0.314955\end{array}$ & $\begin{array}{l}0.189294 \\
0.044544 \\
0.473958 \\
0.045028\end{array}$ & $\begin{array}{c}0.237871 \\
0.535917 \\
-0.000064 \\
-\end{array}$ & $\begin{array}{c}0.169619 \\
- \\
0.189294\end{array}$ & $\begin{array}{c}- \\
- \\
0.520832 \\
-\end{array}$ \\
\hline 80 & $\begin{array}{l}2 \\
3 \\
6 \\
9 \\
\end{array}$ & $\begin{array}{l}0.604279 \\
0.400008 \\
1.445251 \\
0.395721 \\
\end{array}$ & $\begin{array}{l}0.265950 \\
0.069555 \\
0.500040 \\
0.069262\end{array}$ & $\begin{array}{c}0.260431 \\
0.66849 \\
-0.000124 \\
- \\
\end{array}$ & $\begin{array}{c}- \\
0.279089 \\
- \\
0.265950\end{array}$ & $\begin{array}{c}- \\
- \\
0.554262 \\
- \\
\end{array}$ \\
\hline 90 & $\begin{array}{l}2 \\
3 \\
6 \\
9 \\
\end{array}$ & $\begin{array}{l}0.626968 \\
0.696949 \\
1.374385 \\
0.373032 \\
\end{array}$ & $\begin{array}{l}0.361603 \\
0.378746 \\
0.584181 \\
0.093355\end{array}$ & $\begin{array}{c}0.258170 \\
0.376804 \\
-0.000143 \\
- \\
\end{array}$ & $\begin{array}{c}- \\
0.093721 \\
- \\
0.361603\end{array}$ & $\begin{array}{c}- \\
- \\
0.559184 \\
-\end{array}$ \\
\hline 100 & $\begin{array}{l}2 \\
3 \\
6 \\
9\end{array}$ & $\begin{array}{l}0.602893 \\
0.877247 \\
1.806278 \\
0.397107\end{array}$ & $\begin{array}{l}0.357764 \\
0.429614 \\
0.716425 \\
0.101425\end{array}$ & $\begin{array}{c}0.283496 \\
0.416691 \\
-0.000182 \\
-\end{array}$ & $\begin{array}{c}- \\
0.103317 \\
- \\
0.357764\end{array}$ & $\begin{array}{c}- \\
- \\
0.526191 \\
-\end{array}$ \\
\hline
\end{tabular}

Table 4. Equations of dependence of coefficients of Verna model as a function of temperature

\begin{tabular}{ccc}
\hline Equation & $\mathbf{R}^{2}(\%)$ & \\
$\hat{\mathrm{k}}=0.001653^{* *} \mathrm{~T}-0.062201$ & 97.27 & $(16)$ \\
$\hat{\mathrm{g}}=0.005636^{*} * \mathrm{~T}-0.184143$ & 95.80 & $(17)$ \\
$\overline{\mathrm{a}}=0.37742$ & & $(18)$ \\
\hline
\end{tabular}

Significant at $1 \%$ probability by "t" test

Figure 3 presents observed and estimate values by Verna model, with its coefficients described as a function of temperature, in which one may observe an excellent correlation between values.

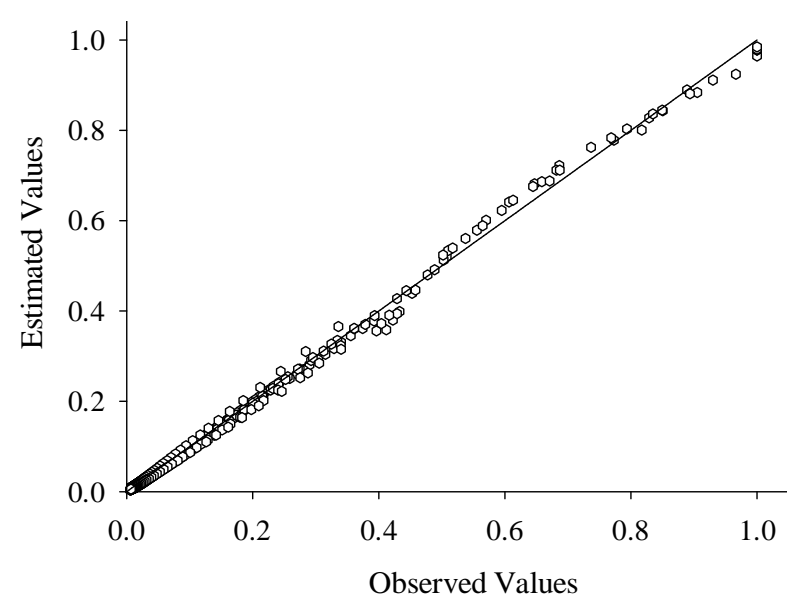

Figure 3. Correlation between observed and estimate values by Verna model, with its coefficients described as a function of temperature
Table 5 presents the values for effective diffusion coefficients, $D_{\text {ef, }}$ for carrot slices under six different temperatures.

Table 5. Effective diffusion coefficients of carrot slices for each drying temperature

\begin{tabular}{cc}
\hline Temperature $\left({ }^{\circ} \mathbf{C}\right)$ & Diffusion coefficient $\left(\mathbf{m}^{2} \mathbf{s}^{-1}\right)$ \\
50 & $8.94 \times 10^{-10}$ \\
60 & $1.25 \times 10^{-09}$ \\
70 & $1.61 \times 10^{-09}$ \\
80 & $2.32 \times 10^{-09}$ \\
90 & $3.22 \times 10^{-09}$ \\
100 & $3.57 \times 10^{-09}$ \\
\hline
\end{tabular}

From Table 5 it is possible to observe that effective diffusion coefficient for carrot slices increased as temperature increased, in which are in accordance to those mentioned in literature for drying processes of agricultural products. According to Madamba et al. (1996), those presented values ranging from $10^{-11}$ to $10^{9} \mathrm{~m}^{2} \mathrm{~s}^{-1}$. These coefficients are in accordance to those found in infrared drying researches, such as Umesh Hebbar \& Rastogi (2001), who observed diffusion coefficients for cashew kernel of $0.948 \times 10^{-9}$ to $2.2 \times 10^{-9} \mathrm{~m}^{2} \mathrm{~s}^{-1}$ in temperature range of 100 to $120^{\circ} \mathrm{C}$. Higher values were found by Toğrul (2006), who determined effective diffusion coefficient values ranging from $7.295 \times 10^{-11}$ to $1.501 \times 10^{-10} \mathrm{~m}^{2} \mathrm{~s}^{-1}$, for temperatures from 50 to $80^{\circ} \mathrm{C}$.

As temperature increases, water viscosity decreases; and, as viscosity measures flowing resistance of a fluid, variation of this property leads to alteration of water diffusion in capillary porous media, which contributes to fluid movements in the 
product. Furthermore, as temperature increases, the level of molecular vibration in water molecules increases, which also contributes to greater diffusion of the fluid in its environment. Afzal \& Abe (1998), discussed that as radiation intensity increases, intern temperature of the product submitted to drying process significantly increases, and as a consequence, an increase of diffusion occurs.

A variation of the effective diffusion coefficient as a function of temperature is described by Ahrrenius representation, as shown by Figure 4 .

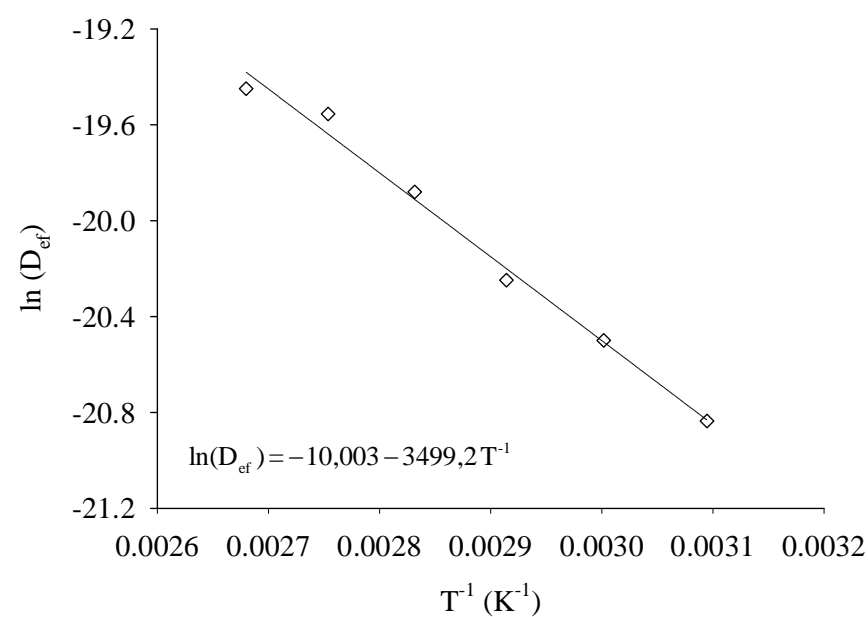

Figure 4. Arrhenius representation for effective diffusion coefficients $\left(D_{\text {ef }}\right)$ of carrot slices under different drying temperatures

From Figure 4 is possible to observe that effective diffusion coefficients linearly varied as temperature increased, which proves uniformity of the phenomenon during drying processes within the temperature range under study.

The activation energy for water diffusion in carrot slices during drying processes within the range of temperature under study was $29.092 \mathrm{~kJ} \mathrm{~mol}^{-1}$. According to Zogzas et al. (1996) this result is reasonable. Once considering agricultural products, the value for activation energy ranges from 12.7 to $110 \mathrm{~kJ} \mathrm{~mol}^{-1}$. This value is in accordance to those found by Doymaz (2004), who found activation energy value of $28.36 \mathrm{~kJ}$ $\mathrm{mol}^{-1}$ for convective drying of carrots. Toğrul (2006) verified activation energy value of $22.46 \mathrm{~kJ} \mathrm{~mol}^{-1}$ for infrared drying of carrots within temperatures from 50 to $80^{\circ} \mathrm{C}$. This difference is probably due to both facts that in this research temperature range was broader $\left(50\right.$ to $\left.100{ }^{\circ} \mathrm{C}\right)$ and different varieties of the product were analyzed. However, values outside this range can also be found, according observed by Reis et al. (2011) studied convective drying of Pará Cumari pepper, who obtained an activation energy of $5.7 \mathrm{~kJ} \mathrm{~mol}^{-1}$.

Kayacier \& Singh (2004) reported that energy decreased as moisture content increased in the product. In drying processes, as lower the activation energy, higher water diffusivity in the product will occur.

\section{Conclusions}

1. It was verified that drying of carrot slices presents a constant rate of drying from the beginning of infrared drying process and this may be satisfactorily represented by a linear model.

2. Coefficients of heat and mass transfer were determined for a constant drying period, and those significantly varied as temperature did.

3. The Approximation of Diffusion, Two terms, Midili and Verna models satisfactorily represented the falling period of infrared drying for carrot slices.

4. The effective diffusion coefficients for carrot slices ranged from $8.94 \times 10^{-10}$ to $3.57 \times 10^{-9} \mathrm{~m}^{2} \mathrm{~s}^{-1}$, for temperature ranging from 50 to $100{ }^{\circ} \mathrm{C}$; dependence of this coefficient with temperature was verified through Arrhenius relationship. Activation energy found in this research was $29.092 \mathrm{~kJ} \mathrm{~mol}^{-1}$.

\section{LITERATURE CITED}

Afzal, T. M.; Abe, T. Diffusion in potato during infrared radiation drying. Journal of Food Engineering, v.37, p.353-365, 1998.

Bird, R. B.; Stewart, W. E.; Lightfoot, E. N. Transport phenomena. 2nd Edition. New York: John Wiley \& Sons Inc, 2002. 838p.

Brooker, D. B., Bakker-Arkema, F. W.; Hall, C. W. Drying and storage of grains and oilseeds. Westport: The AVI Publishing Company, 1992. 450p.

Doymaz, I. Convective air drying characteristics of thin layer carrots. Journal of Food Engineering, v.61, p.359-364, 2004.

Doymaz, I.; Tuðrul, N.; Pala, M. Drying characteristics of dill and parsley leaves. Journal of Food Engineering, v.77, p.559$565,2006$.

Gely, M. C; Giner, S. A. Diffusion coefficient relationships during drying of soya bean cultivars. Biosystems Engineering, v.96, n.2, p.213-222, 2007.

Gely, M. C.; Santalla, E. M. Moisture diffusivity in quinoa (Chenopodium quinoa Willd.) seeds: Effect of air temperature and initial moisture content of seeds. Journal of Food Engineering, v.78, p.1029-1033, 2007.

Hebbar, H. U.; Rastogi, N. K. Mass transfer during infrared drying of cashew kernel. Journal of Food Engineering, v.47, p.1-5, 2001.

Incropera, F. P.; DeWitt, D. P. Fundamentals of heat and mass transfer, 5th Edition. New York: John Wiley \& Sons Inc, 2002. 698p.

Kayacier, A.; Singh, R. K. Application of effective diffusivity approach for the moisture content prediction of tortilla chips during baking. Swiss Society of Food Science and Technology, v.37, p.275-281, 2004.

Madamba, P. S.; Driscoll, R. H.; Buckle, K. A. Thin-layer drying characteristics of garlic slices. Journal of Food Engineering, v.29, p.75-97, 1996.

Maskan, M. Effect of processing on hydration kinetics of three wheat products of the same variety. Journal of Food Engineering, v.52, p.337-341, 2002.

Mohapatra, D.; Rao, P. S. A thin layer drying model of parboiled wheat. Journal of Food Engineering, v.66, p.513-518, 2005.

Nowak, D.; Lewicki, P. P. Infrared drying of apple slices. Innovative Food Science and Emerging Technologies, v.5, p.353-360, 2004. 
Reis, R. C.; Barbosa, L. S.; Lima, M. L.; Reis, J. S.; Devilla, I. A.; Ascheri, D. P. R. Modelagem matemática da secagem da pimenta Cumari do Pará. Revista Brasileira de Engenharia Agrícola e Ambiental, v.15, n.4, p.347-353, 2011.

Toğrul, H. Suitable drying model for infrared drying of carrot. Journal of Food Engineering, v.77, p.610-619, 2006.
Touré, S.; Kibangu-Nkembo, S. Comparative study of natural solar drying of cassava, banana and mango. Renewable Energy, v.29, p.975-990, 2004.

Zogzas, N. P.; Maroulis, Z. B.; Marinos-Kouris, D. Moisture diffusivity data compilation in foodstuffs. Drying Technology, v.14, n.10, p.2225-2253, 1996. 